Dunamis: Jurnal Teologi dan Pendidikan Kristiani

Volume 6, Nomor 1 (Oktober 2021)

ISSN 2541-3937 (print), 2541-3945 (online)

https://www.sttintheos.ac.id/e-journal/index.php/dunamis

DOI: 10.30648/dun.v6i1.675

\begin{tabular}{|l|l|l|}
\hline Submitted: 26 Oktober 2021 & Accepted: 14 Juni 2021 & Published: 30 Oktober 2021 \\
\hline
\end{tabular}

\title{
Pemahaman Jemaat Tentang Penggunaan Salam Assalamualaikum dalam Liturgi Ibadah Gereja
}

\author{
Anggreani Norma Paat ${ }^{1 *}$; Mieke Yen Manu ${ }^{2}$ \\ Fakultas Ilmu Sosial Keagamaan, Institut Agama Kristen Negeri Kupang ${ }^{1 ; 2}$ \\ anggreanipaat@yahoo.co.id*
}

\begin{abstract}
Theologically, liturgy is a celebration in which God reveals the work of salvation through Jesus. GISKI North Minahasa applies a common liturgical form, but has a uniqueness in the greeting element, namely using assalamualaikum greeting. This study aimed to explain the understanding of the North Minahasa GISKI congregation about the use of assalamualaikum greeting in their religious meeting liturgy and to describe demographic factors that might explain the tendency of variables. This study used quantitative methods with statistical descriptive analysis techniques. The results showed that demographic factors, which were associated with the variables of age, education, ecclesiastical position and age of membership, contributed significantly to respondents' understanding, while gender did not. It could be concluded that the contextualization of the liturgy got a positive response from the congregation member and hds an impact on strengthening their faith.
\end{abstract}

Keywords: liturgy; assalamualaikum greeting; contextualization; inculturation; religious meeting

\begin{abstract}
Abstrak
Secara teologis, liturgi merupakan perayaan dimana Allah menyatakan karya keselamatan melalui Yesus. GISKI Minahasa Utara menerapkan bentuk liturgi yang tidak berbeda, namun memiliki keunikan pada unsur salamnya yaitu menggunakan salam assalamualaikum. Tujuan penelitian ini adalah untuk menjelaskan pemahaman jemaat GISKI Minahasa Utara tentang penggunaan salam assalamualaikum dalam liturgi ibadahnya serta mendeskripsikan faktorfaktor demografi yang sekiranya menjelaskan kecendrungan variabel. Penelitian ini menggunakan metode kuantitatif dengan teknik analisa deskriptif statistik. Hasil penelitian menunjukkan bahwa faktor demografi, yang dikaitkan dengan variabel faktor usia, pendidikan, jabatan gerejawi dan usia keanggotaan, memberikan kontribusi signifikan bagi pemahaman responden, sedangkan faktor jenis kelamin tidak berkontribusi signifikan. Kesimpulan dari penelitian ini adalah bahwa kontekstualisasi liturgi mendapatkan sambutan positif umat dan berdampak penguatan keimanan umat.
\end{abstract}

Kata Kunci: liturgi; salam assalamualaikum; kontekstualisasi; inkulturasi; ibadah 


\section{PENDAHULUAN}

Liturgi merupakan unsur penting dalam kebaktian umat. Dengan adanya tata ibadah maka proses kebaktian menjadi lebih sistematis dan teratur. Bentuk liturgi atau tata ibadah bermacam-macam tergantung pada gereja itu sendiri. Secara praktis, jemaat dipandu dan terbantu dalam mengikuti dan menyelenggarakan kebaktian. Demikian liturgi atau tata ibadah menjadi salah satu perangkat penting dalam gereja. Upaya penyesuaian liturgi juga bukanlah hal baru dalam sejarah gereja, sejak awal gereja berdiri dan melayankan ibadah, selalu diperhadapkan dengan lingkungan sekitar, oleh karenanya liturgi pun berada dalam proses penyesuaian. ${ }^{1}$ Bentuk nyata dari proses ini seperti munculnya model/tata ibadah baru yang akomodir kultur popular saat ini yaitu ibadah kontemporer. ${ }^{2}$ Tata ibadah ini dianut oleh gereja beraliran Pentakosta maupun Kharismatik. Bagi gereja tradisional (mainstream) yang menggunakan tata ibadah baku pun turut mengalami penyesuaian dalam batas tertentu.

\footnotetext{
1 Rasid Rahcman, Pembimbing Kedalam Sejarah Liturgi (Jakarta: BPK Gunung Mulia, 2010).

2 Firman Panjaitan and Marthin Steven Lumingkewas, "Ibadah Jemaat Kristen Kontemporer Abad 21 Dan Tinjauan KritisLiturgis," FIDEI: Jurnal Teologi Sistematika dan Praktika 2, no. 1 (2019): 159-182.

3 Furqon Syarief. Hidayatulloh, "Salam Dalam Perspektif Islam," Jurnal Pendidikan Agama IslamTa'lim 9, no. 1 (2011): 89-94.
}

Gereja Iman Sejati Kaum Imanuel di Minahasa Utara, selanjutnya akan disingkat GISKI Minahasa Utara, menggunakan susunan liturgi yang tidak berbeda dengan liturgi yang umumnya digunakan oleh mayoritas gereja di Minahasa Utara, namun bila dicermati terdapat keunikan yang tidak dimiliki oleh gereja lainnya. Salah satu unsur dalam liturgi adalah salam yang terletak dibagian awal liturgi, dan bagian inilah yang disajikan secara berbeda oleh GISKI Minahasa Utara. Bagian salam ini menggunakan bahasa Arab yaitu assalamualaikum.

Kata assalamualaikum (السلام عليكم as-salāmu 'alaykum) merupakan salam dalam bahasa Arab, dan digunakan oleh budaya Muslim. ${ }^{3}$ Salam ini adalah Sunnah Nabi Muhammad SAW, yang dapat merekatkan Ukhuwah Islamiyah umat Muslim di seluruh dunia. ${ }^{4}$ Bagi orang yang mengucapkan salam, hukumnya adalah sunnah; sedangkan bagi yang mendengarnya, wajib untuk menjawabnya. ${ }^{5}$ Salam ini juga menjadi budaya yang digunakan orang Kristen di wilayah Timur Tengah karena mempunyai arti kedamaian dan kesejahteraan bagi

\footnotetext{
4 Abdul Aziz. Masyhuri, Masalah Keagamaan: Hasil Muktamar Dan Munas Ulama Nahdhatul Ulama I-XXX (1928 s/d 2000) (Jakarta: Agromedia Pustaka, 2004).

5 Herni Nuraini, "Budaya Salam Terhadap Tumbuhnya Nilai-Nilai Keislaman Antar Mahasiswa IAIN Parepare" (IAIN Parepare, 2018).
} 
yang mengucapkan salam dan penerima salam tersebut. Maknanya sejajar dengan salam shalom aleichem dalam bahasa Ibrani, ${ }^{6}$ sehingga salam assalamualaikum dimasukkan dalam tata cara (liturgi) GISKI dan dilestarikan sampai kini.

Berdasarkan sejarahnya, ${ }^{7}$ GISKI adalah persekutuan yang disingkat PISKI (Persekutuan Iman Sejati Kaum Israel). Berasal dari pulau Jawa tahun 1931 dan bergabung dengan KGMPM selama enam bulan dan mulai aktifitas bergereja di Sukur, Kabupaten Minahasa Utara dengan metode pelayanan yang berbeda. Kemudian PISKI berubah menjadi GISKI dengan kepanjangan Gereja Iman Sejati Kaum Imanuel, disebabkan ada ketentuan hukum di Indonesia melalui Bimas Kristen Kementerian Agama yang menyatakan bahwa lembaga keagamaan yang resmi atau legal adalah bernama Gereja bukan Persekutuan. Oleh karena itu, PISKI dengan lambang timbangan didaftarkan menjadi GISKI dan lambangnya berubah menjadi salib. GISKI resmi menjadi lembaga Gereja yang terdaftar di Sulut tahun 1980 dan diusulkan ke Ditjen Bimas Kristen sebagai Sinode secara Nasional.

\footnotetext{
6 Siti Istirokah, "Dampak Pembiasaan Berjabat Tangan dan Mengucapkan Salam terhadap Terbentuknya Sikap Tawadhu' kepada Kedua Orang Tua di SDN Candigaron II Kec. Sumowono Kab. Semarang Tahun 2010" (IAIN SALATIGA, 2010).
}

GISKI masuk ke Minahasa Utara dibawa oleh seorang yang bernama Imanuel Runtuh (Kniel) yang adalah murid dari pengurus Paguyuban Mahardika (Persekutuan Orang-Orang Merdeka) yang terpanggil untuk menginjil di daerah sendiri. Latar belakang berdirinya Paguyuban Mahardika adalah demi kemerdekaan dari cara-cara yang mengikat kekristenan atau gereja, yang pada saat itu dipahami sebagai bentuk tindakan menghakimi (banyak orang keluar dari persekutuan gereja karena tidak tahan). Paguyuban ini juga menjangkau agama lain (Islam) untuk memerdekakan diri agar tidak dibatasi oleh aturan-aturan. Paguyuban ini tidak menonjolkan agama tetapi di dalamnya ada kepercayaan bahwa yang memerdekakan manusia hanya Yesus Kristus (Isa Almasih). Paguyuban ini mengklaim bebas dari segala hukum dan aturan dunia yang mengikat serta memisahkan, namun hanya berkaitan dengan keluarga. Dan di tempat ini aspirasi disalurkan melalui karunia-karunia dalam konteks penginjilan. Ada istilah Palmguna yaitu telapak tangan yang berguna; artinya berkaitan dengan karuniakarunia (potensi, profesi dan lain-lain) yang dipakai untuk kemerdekaan dalam Isa Almasih. Adapun salah satu pengurus inti

\footnotetext{
${ }^{7}$ Semua informasi terkait sejarah GISKI diperoleh melalui wawancara langsung maupun jarak jauh via telepon dengan Ketua dan Pengurus Jemaat.
} 
Paguyuban Mahardika adalah Kyai Sadrak, ${ }^{8}$ tokoh yang dikenal oleh jemaah pribumi Jawa sebagai wong sepuh atau guru yang menyebarkan ngelmu disertai kecakapan supranatural untuk melegitimasi jalan dakwahnya. $^{9}$

Menurut Ketua Sinode GISKI, Pdt. Max Tangkudung, S.Th., MA, ${ }^{10}$ apapun konsep beriman GISKI adalah pemberdayaan jemaat, usaha-usaha untuk kepentingan Gereja melalui Palmguna dan melalui pekerjaan menjangkau orang-orang. Dalam praktek ritus hariannya, GISKI tidak menyebut nama Yesus Kristus melainkan menggunakan sapaan Imanuel atau Injil. Selain itu, nuansa-nuansa Islam juga diangkat dan diyakini oleh GISKI dapat mempersatukan baik dalam keanggotaan gereja maupun seluruh umat manusia.

Berkaitan dengan penelitian yang dilakukan oleh penulis yaitu mengenai salah satu unsur dalam liturgi ibadah GISKI yang disajikan secara berbeda dari gereja lainnya, maka latar belakang berdirinya gereja ini tentu menjadi sumber informasi yang cukup membantu. Dalam pengamatan penulis, misalnya di kota Manado, saat pemimpin ibadah menyampaikan salam dalam kata Ibrani, syalom, maka umat menja-

\footnotetext{
${ }^{8}$ Salah satu tokoh berpengaruh dalam paguyuban yang sudah percaya Injil Isa Almasih (Yesus) dan masih memeluk agama Islam. Diyakini sebagai tokoh yang menginspirasi penggunaan salam assalamualaikum ini dalam liturgi GISKI.
}

wab dengan kalimat "damai di hati." Penggunaan salam seperti ini yang lebih banyak dipakai oleh GMIM (Gereja Masehi Injili Minahasa). Namun GISKI menetapkan penggunaan salam dalam bahasa arab yaitu assalamualaikum ketika menyapa umat dalam proses kebaktiannya.

Fokus utama dalam penelitian ini adalah mencari tahu tingkat pemahaman jemaat GISKI Minahasa Utara tentang penggunaan salam assalamualaikum dalam liturgi ibadahnya. Tujuan dari penelitian ini yaitu untuk memberikan gambaran tingkat pemahaman jemaat mengenai keunikan penggunaan salam assalamualaikum dalam litugi ibadah gereja di Minahasa Utara. Hasil penelitian ini diharapkan dapat memberikan kontribusi bagi kekayaan kreativitas umat gereja di Minahasa Utara, maupun pengembangan sikap toleransi terhadap perbedaan ditengah-tengah kemajemukan bangsa Indonesia.

\section{METODE PENELITIAN}

Peneliti dalam menjawab rumusan masalah dalam penelitian ini, menggunakan metode kuantitatif. Pendekatan yang digunakan ialah survei. Penelitian dengan pendekatan survei tidak melakukan perubahan atau tidak ada perlakuan khusus terhadap

\footnotetext{
9 C. Guillot, Kiai Sadrach: Riwayat Kristenisasi Jawa (Yogyakarta: Mata Bangsa, 2020).

${ }^{10}$ Hasil wawancara dengan Ketua Sinode GISKI.
} 
variabel-variabel yang akan diteliti. ${ }^{11}$ Artinya, informasi diperoleh dari data sebenarnya, yang kemudian dianalisis secara sistematis. Adapun populasi penelitian merupakan seluruh anggota jemaat GISKI di Minahasa Utara; ${ }^{12}$ maka jumlah total populasi adalah 34 responden. Untuk itu, penelitian ini dapat disebut sebagai penelitian populasi karena mengambil semua anggota populasi sebagai responden penelitian. ${ }^{13}$

Instrumen penelitian ini disusun berdasarkan format skala Likert yang terdiri dari lima pilihan jawaban dengan skor yang berbeda. Instrumen melewati pengujian untuk memenuhi syarat pengukuran yaitu sahih (valid) dan terandalkan (reliable). ${ }^{14} \mathrm{Pe}$ ngujian dilakukan terhadap 20 responden dari populasi penelitian menggunakan rumus korelasi Pearson Product Moment. Kemudian melihat nilai $r$ tabel dengan taraf signifikansi 0,05 yaitu sebesar 0,444.

Instrumen terdiri dari 6 butir item yang direncanakan dan dalam pengujian validitas tidak terdapat item drop sehingga dapat digunakan sebagai alat ukur. Pengujian berikutnya uji reliabilitas, yaitu untuk memastikan konsistensi instrumen. Rumus yang digunakan Alpha Cronbach dan

11 Sofian Siregar, Statistik Parametrik Untuk Penelitian Kuantitatif Dilengkapi Dengan Perhitungan Manual Dan Aplikasi SPSS Versi 17 (Jakarta: Bumi Aksara, 2014).

${ }^{12}$ Kecuali anggota jemaat yang masih anal-anak.

${ }^{13}$ Arikunto Suharsimi, Prosedur Penelitian (Jakarta: Rineka Cipta, 2010). diperoleh hasil sebesar 0,871 yang artinya reliabilitas tinggi. Untuk itu, instrumen dapat digunakan untuk mengukur data penelitian.

Data penelitian dianalisa menggunakan pendekatan statistik-deskriptif. Analisa deskriptif dilakukan melihat distribusi frekuensi variabel, perhitungan mean, median, modus, standar deviasi. Selain itu juga digunakan metode analisis data tabulasi silang (cross-tabulation), guna melihat kecenderungan variable berdasarkan skor perolehan. Kecenderungan variabel tersebut dikelompokkan dalam 3 kategori interpretasi nilai yaitu: ${ }^{15}$

$$
\begin{array}{ll}
\text { Tinggi } & : \text { Mi+1SDi } \leq X \\
\text { Sedang } & : \text { Mi-1SDi } \leq X<M i+1 S D i \\
\text { Rendah } & : X<M i-1 S D i
\end{array}
$$

Keterangan:

$\mathrm{Mi}=$ Mean ideal

SDi $=$ Standar deviasi ideal $\mathrm{X}=$ skor

\section{Tabel 1. Kriteria Interpretasi Nilai}

\begin{tabular}{ccc}
\hline $\begin{array}{c}\text { Norma } \\
\text { penilaian }\end{array}$ & $\begin{array}{c}\text { Rentang } \\
\text { skor }\end{array}$ & Interpretasi \\
\hline $\mathrm{Mi}+1 \mathrm{SDi} \geq \mathrm{X}$ & $\geq 22,00$ & Tinggi \\
$\mathrm{Mi}-1 \mathrm{SDi} \leq \mathrm{X}<$ & $14,00-21,5$ & Sedang \\
$\mathrm{Mi}+1 \mathrm{SDi}$ & $<14,00$ & Rendah \\
$\mathrm{X}<\mathrm{Mi}-1 \mathrm{SDi}$ & \\
\hline
\end{tabular}

Adapun setiap pengujian yang dilakukan menggunakan bantuan program komputer yaitu Microsoft Office Excel dan SPSS 25

\footnotetext{
${ }^{14}$ Eliezer Sasmoko, Metode Penelitian, Pengukuran Dan Analisis Data (Tangerang: Harvest Internasional Theological Seminary, 2005).

${ }^{15}$ S. Azwar, Penyusunan Skala Psikologi Edisi 2. (Yogyakarta: Pustaka Pelajar, 2012).
} 
for Windows.

\section{HASIL DAN PEMBAHASAN}

\section{Hasil Penelitian}

Berdasarkan hasil survei terhadap 34 responden, penulis melaporkan data demografi sebagai berikut. Responden lakilaki sebanyak 13 orang, serta responden perempuan sebanyak 21. Kisaran umur responden mulai dari 14 tahun sampai 88 tahun. Tingkat pendidikan mulai dari SMP sampai Strata 2, namun yang mendominasi adalah pendidikan SMA. Pekerjaan responden paling banyak di ranah swasta, bahkan adapula yang tidak bekerja. Dan terdapat 12 responden yang memangku jabatan gerejawi, sedangkan 22 responden lainnya adalah jemaat biasa.

Skor pemahaman jemaat diperoleh dari hasil perhitungan angket dengan 6 butir item yang memiliki rentang skor 1-5, sehingga nilai minimum ideal adalah 6 dan nilai maximum ideal adalah 30 . Data perhitungan disusun dalam 3 kategori penilaian (tinggi, sedang, rendah) untuk mempermudah analisis dengan mengacu pada nilai mean ideal (Mi) dan nilai standar deviasi ideal $(\mathrm{SDi}) . \mathrm{Mi}=1 / 2(30+6)=18$; sedangkan $\mathrm{SDi}=1 / 6(30-6)=4$.

Hasil survei menunjukkan sebaran data pemahaman responden terhadap penggunaan salam assalamualaikum dalam liturgi disajikan dalam tabel 2.
Tabel 2. Sebaran Data Pemahaman Responden

\begin{tabular}{lr}
\hline $\mathrm{N}$ & $\begin{array}{c}\text { Valid } \\
\text { Missing }\end{array}$ \\
\hline Mean & 0 \\
Std. Error of Mean & 24.15 \\
Median & .500 \\
Mode & 24.00 \\
Std. Deviation & 24 \\
Variance & 2.914 \\
Range & 8.493 \\
Minimum & 14 \\
Maximum & 16 \\
Sum & 30 \\
\hline
\end{tabular}

Data di atas menunjukkan bahwa nilai rerata pemahaman responden adalah 24,15, dengan standar deviasi pada angka 2,914 dan varian sebesar 8,493. Secara ringkas, berdasarkan data tersebut dan mengacu pada tabel interpretasi nilai diketahui bahwa tingkat pemahaman jemaat berada dalam kategori tinggi atau dengan nilai rerata sebesar 24,15.

Tabel 3. Data jenis kelamin responden

\begin{tabular}{ccccc}
\hline \multirow{2}{*}{ Skor } & \multicolumn{3}{c}{ Frekuensi } & \multirow{2}{*}{ Kategori } \\
& $\mathrm{L}$ & $\mathrm{P}$ & $\%$ & \\
\hline$\geq 22,00$ & 12 & 19 & 91,18 & Tinggi \\
$14,00-21,5$ & 1 & 2 & 8,82 & Sedang \\
$<14,00$ & 0 & 0 & 0 & Rendah \\
Total & 13 & 21 & 100,00 & \\
\hline
\end{tabular}

Data jenis kelamin dari 34 responden diketahui bahwa responden didominasi oleh perempuan yaitu sebanyak 21 orang $(61,8 \%)$, sedangkan laki-laki sebanyak 13 orang $(38,2 \%)$. Berdasarkan kategori pemahaman dikaitkan dengan jenis kelamin, terdapat 31 responden $(91,18 \%)$ yang berada dikategori tinggi yaitu 12 orang laki-laki dan 19 orang perempuan. Responden yang berada pada kategori ren- 
dah sebanyak 3 orang $(8,82 \%)$ yaitu 1 orang laki-laki dan 2 orang perempuan.

Tabel 4. Data usia responden

\begin{tabular}{lrrr}
\hline \multicolumn{5}{c}{ USIA } & & \\
\multicolumn{1}{c}{ SKOR } & $\geq 22,00$ & $14,00-21,5$ & $<14,00$ \\
Kategori & Tinggi & \multicolumn{1}{c}{ Sedang } & Rendah \\
\hline Remaja awal & 1 & 0 & 0 \\
Remaja akhir & 5 & 0 & 0 \\
Dewasa awal & 1 & 0 & 0 \\
Dewasa akhir & 6 & 0 & 0 \\
Lansia awal & 6 & 0 & 0 \\
Lansia akhir & 7 & 0 & 0 \\
Manula & 5 & 3 & 0 \\
\multicolumn{1}{c}{ Total } & 31 & 3 & 0 \\
\% & 91,18 & 8,82 & 0 \\
\hline
\end{tabular}

Adapun penggolongan usia didasarkan pada klasifikasi yang dikeluarkan oleh Departemen Kesehatan RI tahun 2009. Penggolongan usia tersebut ialah: pertama, usia balita 0-5 tahun. Kedua, usia kanakkanak 6-11 tahun. Ketiga, usia remaja awal 12-16 tahun. Keempat, usia remaja akhir 17-25 tahun. Kelima, usia dewasa awal 2635 tahun. Keenam, usia dewasa akhir 36-45 tahun. Ketujuh, usia lansia awal 46-55 tahun. Kedelapan, usia lansia akhir 56-65 tahun. Kesembilan, usia manula 65 tahun ke atas. ${ }^{16}$ Merujuk pada tabel usia di atas, responden yang disurvei mulai dari golongan remaja awal hingga manula dengan jumlah terbanyak terdapat pada usia manula yaitu 8 orang atau $23,5 \%$. Berdasarkan kategori pemahaman dikaitkan dengan usia responden, semua kelompok usia berada pada kategori tinggi yaitu 31 responden atau 91,18\%; kecuali 3 responden dari kelompok usia manula yang berada pada kategori sedang atau $8,82 \%$.

Tabel 5. Data pendidikan terakhir responden

\begin{tabular}{|c|c|c|c|}
\hline \multicolumn{4}{|c|}{ PENDIDIKAN } \\
\hline SKOR & $\geq 22,00$ & $14,00-21,5$ & $<14,00$ \\
\hline Kategori & Tinggi & Sedang & Rendah \\
\hline SMP & 3 & 2 & 0 \\
\hline SMA & 22 & 1 & 0 \\
\hline D2 & 1 & 0 & 0 \\
\hline $\mathrm{S} 1$ & 4 & 0 & 0 \\
\hline S2 & 1 & 0 & 0 \\
\hline Total & 31 & 3 & 0 \\
\hline$\%$ & 91,18 & 8,82 & 0 \\
\hline
\end{tabular}

Tabel data pendidikan responden menunjukkan tingkat pendidikan mulai dari SMP sebanyak 5 orang $(14,7 \%)$, SMA sebanyak 23 orang $(67,6 \%)$, Diploma 2 sebanyak 1 orang $(2,9 \%)$, Strata 1 sebanyak 4 orang (11,8\%), dan Strata 2 sebanyak 1 orang $(2,9 \%)$. Berdasarkan kategori pemahaman dikaitkan dengan pendidikan, responden yang berada pada kategori sedang sebanyak 3 orang $(8,82 \%)$ berlatar belakang pendidikan SMP (2 orang) dan SMA (1 orang). Sedangkan 31 responden $(91,2 \%)$ lainnya berada pada kategori tinggi.

16 DepkesRI, "Klasifikasi Kelompok Umur," Depkes.Go.Id. 
Tabel 6. Data jabatan gerejawi responden

\begin{tabular}{|c|c|c|c|}
\hline \multicolumn{4}{|c|}{ JABATAN GEREJA } \\
\hline SKOR & $\geq 22,00$ & $\begin{array}{r}14,00 \\
-21,5\end{array}$ & \\
\hline Kategori & Tinggi & Sedang & Rendah \\
\hline Ketua sinode & 1 & 0 & 0 \\
\hline Gembala jemaat & 1 & 0 & 0 \\
\hline Penasehat jemaat & 1 & 0 & 0 \\
\hline Ketua jemaat & 1 & 0 & 0 \\
\hline Wakil ketua jemaat & 1 & 0 & 0 \\
\hline Sekretaris & 1 & 0 & 0 \\
\hline Bendahara & 1 & 0 & 0 \\
\hline Sie kerohanian & 1 & 0 & 0 \\
\hline Penginjil & 1 & 0 & 0 \\
\hline Pendoa & 1 & 0 & 0 \\
\hline Liturgos & 2 & 0 & 0 \\
\hline Jemaat & 19 & 3 & 0 \\
\hline Total & 31 & 3 & 0 \\
\hline$\%$ & 91,18 & 8,82 & 0 \\
\hline
\end{tabular}

Tabel di atas menunjukkan terdapat 11 jabatan gerejawi yaitu ketua sinode, gembala jemaat, penasehat jemaat, ketua jemaat, wakil ketua jemaat, sekretaris, bendahara, sie kerohanian, penginjil, pendoa dan liturgos. Data dari 34 responden diketahui bahwa setiap jabatan masing-masing terdiri dari 1 orang (29\%), kecuali liturgos 2 orang $(5,9 \%)$. Sedangkan 22 orang $(64,7 \%)$ adalah jemaat. Berdasarkan kategori pemahaman dikaitkan dengan jabatan gerejawi, menunjukkan bahwa semua pejabat dalam gereja berada di kategori tinggi. Demikian pula anggota jemaat berada pada kategori sedang hingga kategori tinggi.
Tabel 7. Data usia keanggotaan responden

\begin{tabular}{lrrr}
\hline \multicolumn{4}{c}{ USIA KEANGGOTAAN } \\
SKOR & $\geq 22,00$ & $14,00-21,5$ & $<14,00$ \\
Kategori & Tinggi & Sedang & Rendah \\
\hline 2-16 tahun & 10 & 2 & 0 \\
17-31 tahun & 8 & 0 & 0 \\
32-46 tahun & 4 & 0 & 0 \\
47-61 tahun & 5 & 0 & 0 \\
62-76 tahun & 2 & 0 & 0 \\
77-91 tahun & 2 & 1 & 0 \\
Total & 31 & 3 & 0 \\
\% & 91,18 & 8,82 & 0 \\
\hline
\end{tabular}

Tabel data usia keanggotaan atau lamanya berjemaat dari 34 responden menunjukkan bahwa usia keanggotaan responden mulai dari 2 tahun hingga 77 tahun ke atas. Penulis membagi dalam 6 kelompok untuk memudahkan perhitungan dan pembahasan. ${ }^{17}$ Berdasarkan pembagian kelompok tersebut diperoleh data lamanya responden berjemaat paling banyak pada kelompok keanggotaan 2-16 tahun yaitu 12 orang $(35,3 \%)$ dan yang paling kurang pada kelompok keanggotaan 62-76 tahun yaitu 2 orang $(5,9 \%)$. Berdasarkan kategori pemahaman dikaitkan dengan usia keanggotaan, semua responden berada pada kategori tinggi. Sedangkan responden yang berada pada kategori sedang berasal dari kelompok keanggotaan 2-16 tahun (2 orang) dan dari kelompok keanggotaan $77 \mathrm{ke}$ atas (1 orang).

17 Rumus yang digunakan adalah rumus Sturges $(1+3,3 \log \mathrm{n})$; lih. Sugiyono, Statistika Untuk Penelitian (Bandung: Alfabeta, 2005). 


\section{Pembahasan}

Liturgi sebagai bagian yang melekat erat dengan peribadatan dalam gereja. Setiap unsurnya memiliki peran yang penting, tidak ada salah satu bagian yang mendominasi atau lebih bermakna dari unsur lainnya. Penelitian ini menyoroti salah satu unsur yang berada tepat diawal sebuah liturgi yaitu unsur salam. Unsur salam dalam liturgi memiliki makna penanda persekutuan, ${ }^{18}$ bahwa ketika salam diucapkan oleh pelayan dan disahuti oleh jemaat, memberi gambaran yang jelas mengenai persekutuan yang terjalin di antara umat dan bersama Tuhan.

Dalam proses analisis data, penulis menggunakan perhitungan Crosstab untuk mengidentifikasi faktor-faktor demografik yang sekiranya dapat memperjelas kecenderungan variable yang diteliti. Faktor-faktor tersebut meliputi: jenis kelamin, usia, pendidikan terakhir, jabatan gerejawi dan usia keanggotaan jemaat.

Berdasarkan tabel jenis kelamin, diketahui responden didominasi jenis kelamin perempuan sebanyak $61,8 \%$, sedangkan responden dengan jenis kelamin laki-laki sebasar 38,2\%. Dan tingkat pemahaman responden yang berjenis kelamin laki-laki maupun perempuan sama-sama berada pada kategori sedang hingga tinggi. Dengan demikian, jenis kelamin bukan faktor yang

${ }^{18}$ Abineno, Unsur-Unsur Liturgia. berarti bagi tingkat pemahaman responden terhadap penggunaan salam assalamualaikum.

Berdasarkan tabel usia, diketahui kelompok usia responden mulai dari remaja awal hingga manula, dengan prosentasi terbanyak pada usia manula yaitu $23,5 \%$, disusul usia lansia akhir, lansia awal dan dewasa akhir. Sebaran tingkat pemahaman responden untuk semua kelompok usia yang disurvei berada pada kategori tinggi. Pertambahan usia idealnya berpengaruh pada meningkatkan pemahaman seseorang seiring dengan perolehan pengetahuan sepanjang hidupnya. Namun pertambahan usia juga menyebabkan penurunan kerja tubuh sehingga mengalami penurunan kemampuan menerima dan memproses informasi. Menurut Azizah, penambahan umur manusia secara alami memberikan dampak berupa perubahan pada dirinya karena proses penuaan yang degenaratif, salah satunya adalah penurunan aspek kognitif seperti daya ingat, IQ, kemampuan belajar, pemahaman, pemecahan masalah, pengambilan keputusan, kebijaksanaan, kinerja dan motivasi. ${ }^{19}$ Dalam penelitian ini, beberapa responden dari kelompok usia manula berada pada kategori sedang yang menunjukkan bahwa penurunan daya kognitif (pemahaman) terjadi pada responden. Namun karena kuantitasnya sangat kecil yaitu 3 respon-

\footnotetext{
${ }^{19}$ Lilik Ma'rifatul Azizah, Keperawatan Lanjut Usia (Yogyakarta: Graha Ilmu, 2011).
} 
den saja maka tidak memberikan kontribusi yang berarti; selain itu masih terdapat 5 responden lain dari kelompok usia manula yang berada pada kategori tinggi. Dengan demikian, usia termasuk faktor yang berarti bagi tingkat pemahaman responden terhadap penggunaan salam assalamualaikum.

Tabel tingkat pendidikan menunjukkan bahwa responden sebagian besar berpendidikan SMA $(67,6 \%)$; tingkat pendidikan terendah adalah SMP $(14,7 \%)$ dan tingkat pendidikan tertinggi adalah S2 (2,9\%). Sebaran tingkat pemahaman responden untuk semua jenjang pendidikan berada pada kategori tinggi. Responden yang berada pada kategori sedang adalah responden dengan tingkat pendidikan SMP (2 orang) dan SMA (1 orang). Dalam penelitian ini, jelas terlihat bahwa tingkat pendidikan yang tinggi dapat memberikan pengaruh yang signifikan pada pemahaman seseorang. Karena penulis hanya mengukur tingkat pendidikan formal, sehingga dapat dikatakan pendidikan formal memberi kontribusi yang berarti bagi pemahaman responden terhadap penggunaan salam assalamualaikum dalam liturgi ibadahnya.

Berdasarkan tabel jabatan gerejawi, diperoleh 11 jabatan gerejawi yaitu ketua sinode, gembala jemaat, penasehat jemaat,

${ }^{20}$ Dessy Handayani, “Isu-Isu Kontemporer Dalam Jabatan Gerejawi," Kurios (2018).

21 Bakhoh Jatmiko, “Optimalisasi Fungsi-Fungsi Jabatan Kepemimpinan Gerejawi Sebagai Salah ketua jemaat, wakil ketua jemaat, sekretaris, bendahara, sie kerohanian, penginjil, pendoa dan liturgos. Data menunjukkan bahwa semua responden yang memangku jabatan dalam gereja berada pada kategori tinggi, demikian pula anggota jemaat biasa. Sedangkan responden yang berada pada kategori sedang adalah anggota jemaat biasa. Seseorang yang memangku jabatan dalam organisasi tentu saja harus memahami dan menghayati visi/misi organisasi. Pada hakekatnya jabatan gerejawi lahir dari kebutuhan umat untuk melayani umat bagi pembangunan umat. ${ }^{20}$ Jabatan dalam gereja berkaitan dengan pelaksanaan peran dan fungsi penatalayanan umat secara optimal. ${ }^{21}$ Temuan ini menunjukkan bahwa responden yang memiliki jabatan dalam gereja memiliki pemahaman yang tinggi terhadap penggunaan salam assalamualaikum dan tentu saja hal ini berkontribusi bagi pemahaman responden yang juga berada pada kategori tinggi.

Faktor demografi lain yang dikaitkan dengan tingkat pemahaman responden adalah lamanya berjemaat atau usia keanggotaan responden. Usia keanggotaan dimulai dari 2 tahun hingga 88 tahun, penulis mengelompokkannya dalam 6 kelas dengan

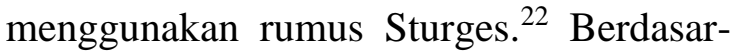

Satu Perwujudan Pelayanan Yang Holistik," SANCTUM DOMINE: JURNAL TEOLOGI (2020).

${ }^{22}$ Sugiyono, Statistika Untuk Penelitian. 
kan tabel usia keanggotaan diketahui bahwa responden paling banyak dari kelompok keanggotaan 2-16 tahun $(35,3 \%)$ dan yang paling sedikit dari kelompok keanggotaan 62-76 tahun $(5,9 \%)$. Responden yang berada pada kategori tinggi berasal dari semua kelompok usia keanggotaan. Sedangkan responden pada kategori sedang berasal dari keanggotaan 2-16 tahun (2 orang) dan keanggotaan 77 tahun ke atas (1 orang). Temuan ini sangat kasuistik karena kuantitasnya sangat kecil sehingga tidak cukup berarti. Penulis berpendapat mungkin saja responden mengalami kendala tersendiri hingga mempengaruhi kinerjanya ketika survei ini dilakukan. Data ini juga menunjukkan bahwa responden yang disurvei didominasi oleh anggota jemaat yang baru, namun memiliki tingkat pemahaman yang tinggi terhadap penggunaan salam assalamualaikum dalam liturgi gerejanya.

Berdasarkan kecenderungan data penelitian yang diperoleh, maka dapat diringkas bahwa pemahaman jemaat mengenai penggunaan salam assalamualaikum dalam liturgi berada pada kategori sedang hingga tinggi. Responden yang berada pada kategori sedang adalah responden dari kelompok usia manula yang sangat mungkin mengalami kemunduran daya paham karena usia. Selain itu responden hanya berlatar belakang pendidikan SMP dan SMA, juga berstatus sebagai anggota jemaat biasa.
Ditilik dari lamanya berjemaat, responden yang berada pada kategori sedang adalah responden dari usia keanggotaan terbaru dan usia keanggotaan terlama. Jadi dapat dikatakan responden dari tahun awal masih membutuhkan waktu untuk memahami asas dasar GISKI, sedangkan responden dari tahun keanggotaan terlama sangat mungkin mengalami penurunan daya ingat atau pemahaman karena proses penuaan. Namun demikian perlu ditekankan bahwa temuan ini diketahui kuantitasnya sangat kecil sehingga bersifat kasuistik, lagipula dapat dijelaskan berdasarkan fakta demografi yang menyertainya. Selain itu, sangat jelas bahwa tidak ada responden yang berada pada kategori rendah sehingga dipastikan bahwa jemaat memahami penggunaan salam asalamualaikum dalam liturgi ibadah GISKI.

\section{Implikasi}

Seiring dengan pekembangan dunia yang semakin kompleks, maka gereja perlu membenahi diri untuk tetap bertahan dalam arus perubahan zaman ini. Sejarah mencatat bahwa liturgi gereja mengalami pergumulan yang cukup berarti setiap bersentuhan dengan konteks tertentu. Dalam konteks tanah air, ada beberapa istilah yang digunakan untuk mengenali setiap tahapan perubahan yang terjadi di bidang liturgi. Istilah tersebut ialah adaptasi, akomodasi, inkultu- 
rasi, akulturasi, interkulturasi, kontekstualisasi, pemribumian atau indigenisasi. ${ }^{23} \mathrm{Be}$ lakangan istilah yang popular di bidang liturgi adalah inkulturasi yang menunjukkan suatu interaksi aktif dari liturgi dengan realitas religious ataupun budaya setempat.

Berdasarkan hasil penelitian, keunikan yang dimiliki dalam susunan liturgi GISKI Minahasa Utara masih berada pada tahap akomodasi liturgi. Tahap ini adalah tahap yang paling awal atau sederhana dalam bidang liturgi. Dalam tahap akomodasi liturgi, proses penyesuaian tidak berkaitan langsung dengan budaya setempat atau dengan kata lain hanya secara lahiriah guna kesesuaian dengan kelompok umat terkait perayaan ritus. ${ }^{24}$ Secara garis besar susunan liturgi GISKI Minahasa Utara tidak berbeda dengan gereja Kristen lainnya, hanya mengalami penyesuaian di bagian unsur salam menggunakan kata assalamualaikum. Penulis berpendapat bahwa unsur ini disesuaikan guna menyelaraskan dengan visi penjangkauan jiwa yang diusung oleh GISKI sendiri.

Adapun berdirinya GISKI Minahasa Utara masih berkaitan erat dengan Paguyuban Mahardika dari pulau Jawa yang berlatar belakang agama Islam. Berdasarkan keterangan dari Ketua Sinode GISKI, seperti yang dikemukan di bagian pendahuluan tu-

23 Bernardus Boli Ujan, "Penyesuaian Dan Inkulturasi Liturgi," JUMPA (Jurnal Masalah Pastoral) 1, no. 01 (2012): 14. lisan ini, bahwa konsep teologi dan beriman GISKI sejalan dengan visi paguyuban yang hendak menyiarkan Kristus (Isa Almasih) sebagai jalan kebenaran yang memerdekakan umat. Nuansa dan asas Islamiah masih dipertahankan demi penjangkau jiwa yang lebih luas dan sebagai sarana pemersatu umat. Salah satunya adalah penggunaan salam assalamualaikum dilestarikan dalam ritus kebaktian GISKI. Lagipula secara konsep, arti salam assalamualaikum memiliki kesejajaran makna dengan salam shalom (Bahasa Ibrani) yang lazim di kalangan gereja Kristen; tentu saja hal ini dipahami oleh jemaat GISKI dengan sangat baik sesuai hasil penelitian ini.

\section{KESIMPULAN}

Liturgi dapat mengalami kontekstualisasi, dalam hal ini akomodasi, dengan tradisi atau konteks sosial budaya masyarakat. Upaya kontekstualisasi liturgi tersebut ternyata mendapatkan respon positif umat, di mana upaya tersebut tidak serta merta dipahami sebagai tindakan sinkretik, namun justru membantu umat dalam konteks tertentu untuk lebih dapat memahami keimanannya. Dengan demikian, konteks sosial budaya masyarakat tidak perlu terus dinilai negative ketika berhadapan dengan ajaran-ajaran Kristiani.

${ }^{24}$ Ibid. 


\section{UCAPAN TERIMA KASIH}

Penyusunan naskah ini dapat selesai oleh karena dukungan dan kerja sama yang baik dengan penulis kedua. Terima kasih kepada penulis kedua telah berperan menambahkan materi dari artikel ilmiah dan menyusunnya dengan menggunakan Mendeley. Semoga penelitian ini bermanfaat untuk pembaca.

\section{DAFTAR PUSTAKA}

Abineno, J.L.Ch. Unsur-Unsur Liturgia. Jakarta: BPK Gunung Mulia, 2007.

Azizah, Lilik Ma'rifatul. Keperawatan Lanjut Usia. Yogyakarta: Graha Ilmu, 2011.

Azwar, S. Penyusunan Skala Psikologi Edisi 2. Yogyakarta: Pustaka Pelajar, 2012.

DepkesRI. "Klasifikasi Kelompok Umur." Depkes.Go.Id.

Guillot, C. Kiai Sadrach: Riwayat Kristenisasi Jawa. Yogyakarta: Mata Bangsa, 2020.

Handayani, Dessy. "Isu-Isu Kontemporer Dalam Jabatan Gerejawi." Kurios (2018).

Hidayatulloh, Furqon Syarief. "Salam Dalam Perspektif Islam." Jurnal Pendidikan Agama Islam-Ta'lim 9, no. 1 (2011): 89-94.

Istirokah, Siti. "Dampak Pembiasaan Berjabat Tangan dan Mengucapkan Salam terhadap Terbentuknya Sikap Tawadhu' kepada Kedua Orang Tua di SDN Candigaron II Kec. Sumowono Kab. Semarang Tahun 2010." IAIN SALATIGA, 2010.
Jatmiko, Bakhoh. "Optimalisasi FungsiFungsi Jabatan Kepemimpinan Gerejawi Sebagai Salah Satu Perwujudan Pelayanan Yang Holistik." SANCTUM DOMINE: JURNAL TEOLOGI (2020).

Masyhuri, Abdul Aziz. Masalah Keagamaan: Hasil Muktamar Dan Munas Ulama Nahdhatul Ulama IXXX (1928 s/d 2000). Jakarta: Agromedia Pustaka, 2004.

Nuraini, Herni. "Budaya Salam Terhadap Tumbuhnya Nilai-Nilai Keislaman Antar Mahasiswa IAIN Parepare." IAIN Parepare, 2018.

Panjaitan, Firman, and Marthin Steven Lumingkewas. "Ibadah Jemaat Kristen Kontemporer Abad 21 Dan Tinjauan Kritis-Liturgis." FIDEI: Jurnal Teologi Sistematika dan Praktika 2, no. 1 (2019): 159-182.

Rahcman, Rasid. Pembimbing Kedalam Sejarah Liturgi. Jakarta: BPK Gunung Mulia, 2010.

Sasmoko, Eliezer. Metode Penelitian, Pengukuran Dan Analisis Data. Tangerang: Harvest Internasional Theological Seminary, 2005.

Siregar, Sofian. Statistik Parametrik Untuk Penelitian Kuantitatif Dilengkapi Dengan Perhitungan Manual Dan Aplikasi SPSS Versi 17. Jakarta: Bumi Aksara, 2014.

Sugiyono. Statistika Untuk Penelitian. Bandung: Alfabeta, 2005.

Suharsimi, Arikunto. Prosedur Penelitian. Jakarta: Rineka Cipta, 2010.

Ujan, Bernardus Boli. "Penyesuaian Dan Inkulturasi Liturgi." JUMPA (Jurnal Masalah Pastoral) 1, no. 01 (2012): 14. 